DOI: 10.25140/2411-5215-2021-2(26)-18-24

Альона Ревко, Наталія Приходько

\title{
СОЦІАЛЬНО-ЕКОНОМІЧНІ НАСЛІДКИ БЕЗРОБІТТЯ НАСЕЛЕННЯ РЕГІОНІВ УКРАЇНИ
}

\author{
Alona Revko, Natalia Pryhodko

\section{SOCIO-ECONOMIC CONSEQUENCES OF UNEMPLOYMENT OF THE POPULATION IN THE REGIONS OF UKRAINE}

\begin{abstract}
Стаття присвячена дослідженню сутності безробіття та визначенню його сочіально-економічних наслідків. Встановлено базові фактори, що спричиняють безробіття в Украӥні. Проаналізовано чисельність безробітного населення в регіонах Украӥни у 2019 роиі. Проведено дослідження з метою визначення ставлення молоді м. Чернігова до проблеми безробіття, розуміння иььго соиіально-економічного явища та його наслідків. Доведено, що безробіття призводить до ряду негативних соиіально-економічних наслідків та підвищує рівень соиіальної напруги серед населення регіонів України. Виявлено, що значний негативний вплив на поширення безробіття в регіонах Украйни мала пандемія COVID-19. Встановлено, що безробіття має суттєві соиіально-економічні наслідки, серед яких виділено: зростання злочинності; зниження рівня життя населення регіонів; зниження професійної кваліфікаиії працівників; трудова міграчія населення; збільшення числа самогубств та поширення психічних захворювань серед безробітних. Обтрунтовано, щь ключовими напрямами подолання безробіття в регіонах України має бути: легалізаиія тіньової зайнятості; популяризаиія та державна підтримка самозайнятості; розвиток дуальної освіти; зниження податків для підприємств та інтеграція осіб з особливими потребами до ринку прачі.

Ключові слова: безробіття; фактори безробіття; людський потениіал; робоча сила; дуальна освіта; сочіальне підприємництво.

Рис.: 4. Бібл.: 16

The article is devoted to the study of the essence of unemployment and determining its socio-economic consequences. The basic factors that cause unemployment in Ukraine have been identified. The number of unemployed population in the regions of Ukraine in 2019 is analyzed. A study was conducted to determine the attitude of young people in Chernihiv city to the problem of unemployment, understanding of this socio-economic phenomenon and its consequences. It is proved that unemployment leads to a number of negative socio-economic consequences and increases the level of social tension among the population of the regions of Ukraine. It was found that the COVID-19 pandemic had a significant negative impact on the spread of unemployment in the regions of Ukraine. It is established that unemployment has significant socio-economic consequences, among which are: the growth of crime; declining living standards of the population of the regions; reduction of professional qualification of employees; labor migration; increasing the number of suicides and the spread of mental illness among the unemployed. It is substantiated that the key areas for overcoming unemployment in the regions of Ukraine should be: legalization of shadow employment; promotion and state support of self-employment; development of dual education; reduction of taxes for enterprises and integration of people with special needs into the labor market.
\end{abstract}

Keywords: unemployment; unemployment factors; human potential; workforce; dual education; social entrepreneurship.

Fig.: 4. References: 16.

JEL Classification: E24; J2; J64; R1

Постановка проблеми. Нині Україна перебуває в нестабільній політичній ситуації, що чітко відображається на соціально-економічних аспектах життєдіяльності країни та iii регіонів. Слід зазначити, що ведення військових дій на Сході нашої держави призвело до погіршення соціальної ситуації в країні та довготривалої економічної кризи, яка, зі свого боку, позначилась на дисбалансі всіх соціально-економічних показників. Результатом дестабілізації є спад інвестиційної привабливості, зниження виробництва та рівня життя населення регіонів, значне зростання інфляції та безробіття.

Важливо зазначити, що нині безробіття є актуальною проблемою для населення регіонів України. В умовах переходу нашої держави до ринкової економіки і поглиблення кризових процесів в усіх сферах господарювання, що спіткали Україну в останні роки, неабиякої актуальності набула проблема функціонування та розвитку бізнесу, в тому числі й соціального та, як наслідок, поширення безробіття. Слід зазначити, що безробіття є соціально-економічним явищем, за яким частина економічно активного населення не має можливості знайти гідну роботу і водночас поповнює резервний запас праці, стаючи абсолютно надлишковим щодо ефективності людського капіталу.

Для дослідження проблеми безробіття насамперед варто зазначити причини цього негативного соціально-економічного явища. Однією з базових причин безробіття в регіонах України є спад внутрішнього виробництва i, як наслідок, зменшення кількості ро- 
ТЕОРЕТИЧНІ ПРОБЛЕМИ РОЗВИТКУ НАЦІОНАЛЬНОЇ ЕКОНОМІКИ

бочих місць. Іншою, не менш важливою причиною, є той факт, що економіка нашої країни страждає від циклічного спаду. Більше того, різкий перехід до автоматизації технологічних процесів виробництва спричиняє зростання безробіття.

Аналіз останніх досліджень і публікацій. Питанням дослідження теоретичних основ та соціально-економічних наслідків безробіття присвячено праці багатьох учених: Ж. Дерій [5], М. Нечипоренко [8], П. Нікіфоров [9], О. Севрук, Т. Севрук [12], С. Слюcap [13] та інші.

Виділення недосліджених частин загальної проблеми. Незважаючи на значний науковий доробок вітчизняних та закордонних науковців щодо причин та наслідків безробіття, ця соціально-економічна проблема все ще потребує більш грунтовного дослідження та виявлення напрямів подолання безробіття в регіонах України.

Мета статті. Головною метою цієї публікації є дослідження соціально-економічних наслідків безробіття регіонах України та напрямів їх подолання.

Виклад основного матеріалу. На сучасному етапі розвитку науки існує певна кількість наукових праць, предметом дослідження яких є причини, умови та фактори безробіття як соціально-економічного явища. Учені різних галузей науки досліджували різноманітні аспекти соціально-економічного феномену безробіття, що дає змогу комплексно розглянути наявні проблеми досліджуваного об'єкта.

Як стверджує Державна служба зайнятості України, безробіття - це явище соціально-економічне, внаслідок якого частина населення, яке вважається працездатним (економічно активне населення) не має змоги знайти гідну роботу і відповідно до цієї обставини поповнює резервний запас праці, що $\epsilon$ порівняно надлишковим щодо ефективності саме людського капіталу [3].

Більше того, деякі науковці зазначають, що безробіття є одним з основних соціальних ризиків щодо підтримки людей у сучасному суспільстві [7]. На наше переконання, найважливішим показником стану ринку праці та економіки загалом є саме рівень безробіття. Він відображає рівень використання головної продуктивної сили суспільства людського потенціалу та можливості його капіталізації.

Згідно з методологією Міжнародної організації праці (МОП), безробітними є особи (зареєстровані, а також офіційно незареєстровані в Державній службі зайнятості України), які відповідають усім трьом базовим критеріям:

1) не мають на цей час офіційної роботи;

2) наполегливо шукали роботу або намагалися започаткувати власну діяльність;

3) протягом двох тижнів мали можливість приступити до виконання певної роботи, включаючи роботу на дому з оплатою або підтримкою доходу [10].

Важливо зауважити, що безробіття - це макроекономічна проблема, що зумовлена певними факторами, зокрема зміни в економіці, уповільнення економічного зростання, співвідношення цін на базові фактори виробництва, недостатня сукупність попиту, інфляція, що сприяє зменшення капітальних вкладень, зменшення реальних доходів, котра збільшує кількість пропозиції на робочу силу зі зменшенням іiі попиту, співвідношення цін на базові фактори виробництва, що додають переваг практичним технологіям, сезонні обсяги виробництва, які забезпечують попит із питань праці, науково-технічного прогресу, що збільшує диспропорцію між попитом та пропозиція робочої сили, недосконале законодавство про працю, низький рівень професійного навчання та перепідготовки, неадекватний рівень програми зайнятості та демографічні процеси, що мають місце в Україні [1].

3 огляду на це, до базових факторів, що спричиняють безробіття, належать:

- відсутність сукупного платоспроможного попиту;

- низька мобільність наявної робочої сили; 
- наявні структурні зміни в економіці;

- існуюча дискримінація на ринку праці, зокрема жінок, молоді, а також національних меншин;

- демографічні зміни чисельності та складу наявної робочої сили;

- зниження сезонних обсягів рівня виробництва окремих галузей економіки [7].

Невтішна ситуація на ринку праці України зумовлена змінами в економічній та політичній ситуації в нашій країні. Так, у 2019 році найбільша чисельність безробітного населення спостерігалась у Дніпропетровському (118,7 тис. осіб), Донецькому (117,5 тис. осіб) та Запорізькому (77,5 тис. осіб) регіонах України (рис. 1).

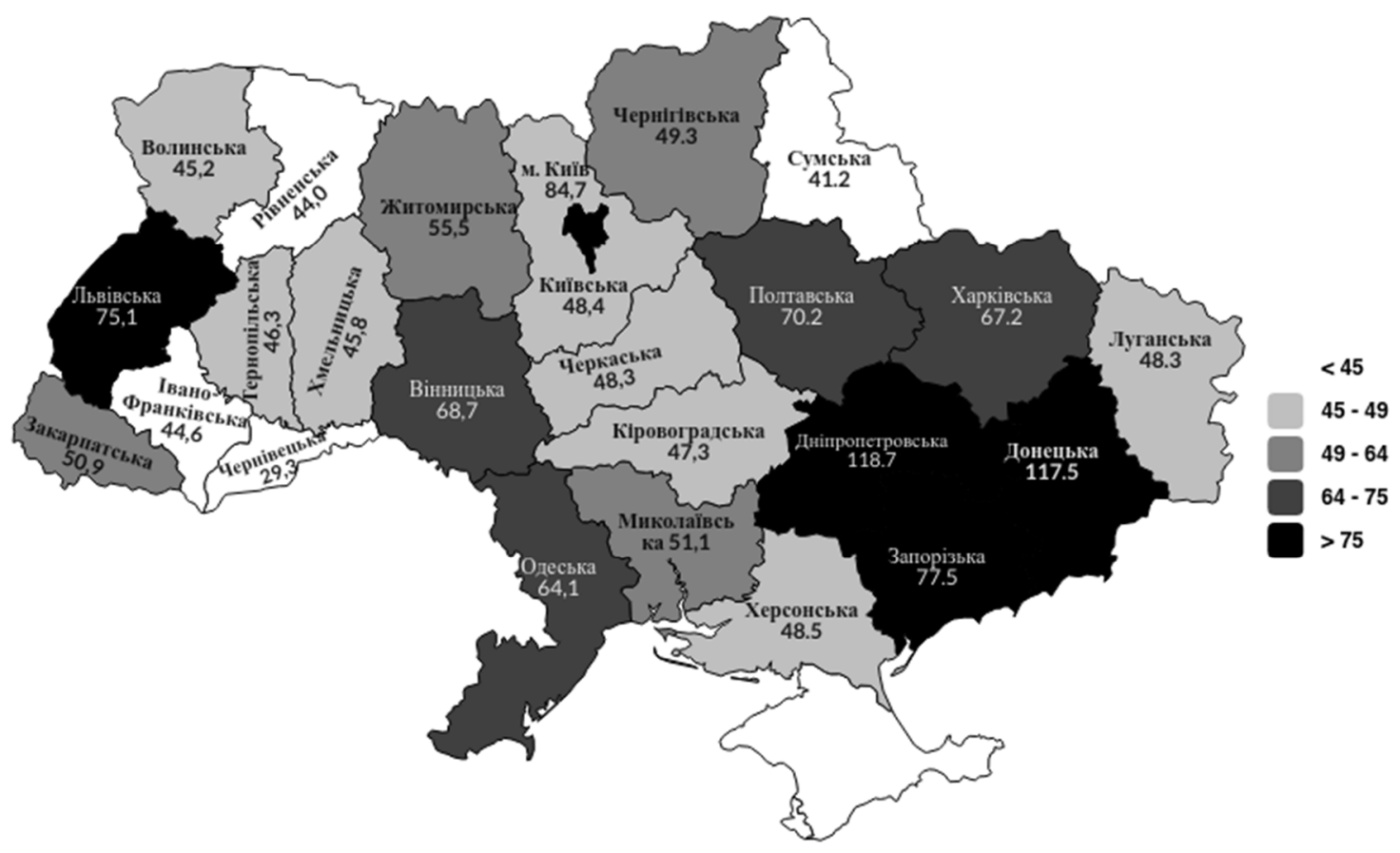

Рис. 1. Чисельність безробітного населення в регіонах Украӥни у 2019 рочі, тис. осіб Джерело: розроблено авторами на підставі даних Державної служби статистики України [3].

Слід зазначити, що співвідношення найбільшої чисельність безробітного населення у Дніпропетровському регіоні (118,7 тис. осіб) та найменшого в Чернівецькому регіоні (29,3 тис. осіб) становить 4 рази. Це є негативним явищем, оскільки не створює рівних можливостей для розвитку людського потенціалу населення регіонів України та його ринкової капіталізації [11, с. 132].

Як зазначає А. Калін, активне регулювання зайнятості має базуватися передусім на державних заходах, спрямованих на профілактику безробіття. Більше того, ефективний вплив на рівень зайнятість має здійснюватися шляхом збалансування попиту та пропозиції на ринку праці. Така соціальна політика пов'язана з державним регулювання ситуації саме на українському ринку праці, а також викликає зростання продуктивність зайнятості та їі вільний вибір.

3 метою визначення ставлення молоді м. Чернігова до проблеми безробіття, розуміння цього соціально-економічного явища та його наслідків нами було проведене дослідження. У дослідженні взяли участь здобувачі вищої освіти Національного університету «Чернігівська політехніка». Вибіркова сукупність становила 38 осіб. В опитуванні був дотриманий гендерний баланс (50\% дівчат та $50 \%$ хлопців). В опитуванні взяли участь здобувачі вищої освіти різних вікових груп (від 16 до 40). 
ТЕОРЕТИЧНІ ПРОБЛЕМИ РОЗВИТКУ НАЦІОНАЛЬНОЇ ЕКОНОМІКИ

Основним методичним інструментом дослідження ставлення молоді до проблеми безробіття виступила розроблена нами анкета, котра містила 17 питань.

Результати анкетування засвідчили, що більшість респондентів $(59,9 \%)$ вважає безробіття соціально-економічним явищем, відповідно до якого частина працездатного населення не має можливості знайти роботу. До безробітних більшість опитаних $(53,5$ \%) відносять осіб, що не мають на цей час офіційної роботи, активно займаються ії пошуками і готові нині почати працювати.

До причин безробіття в умовах сьогодення більшість респондентів (50,2\%, або 19 осіб) відносить пандемію COVID-19 та пов'язані з нею карантинні обмеження. На другому місці серед причин безробіття - спад виробництва на підприємствах, про що зазначили 19,8 \% опитаних. Пошук нових робочих місць 3 метою отримання більшої заробітної плати як причину безробіття вважають 10,2% респондентів (рис. 2).

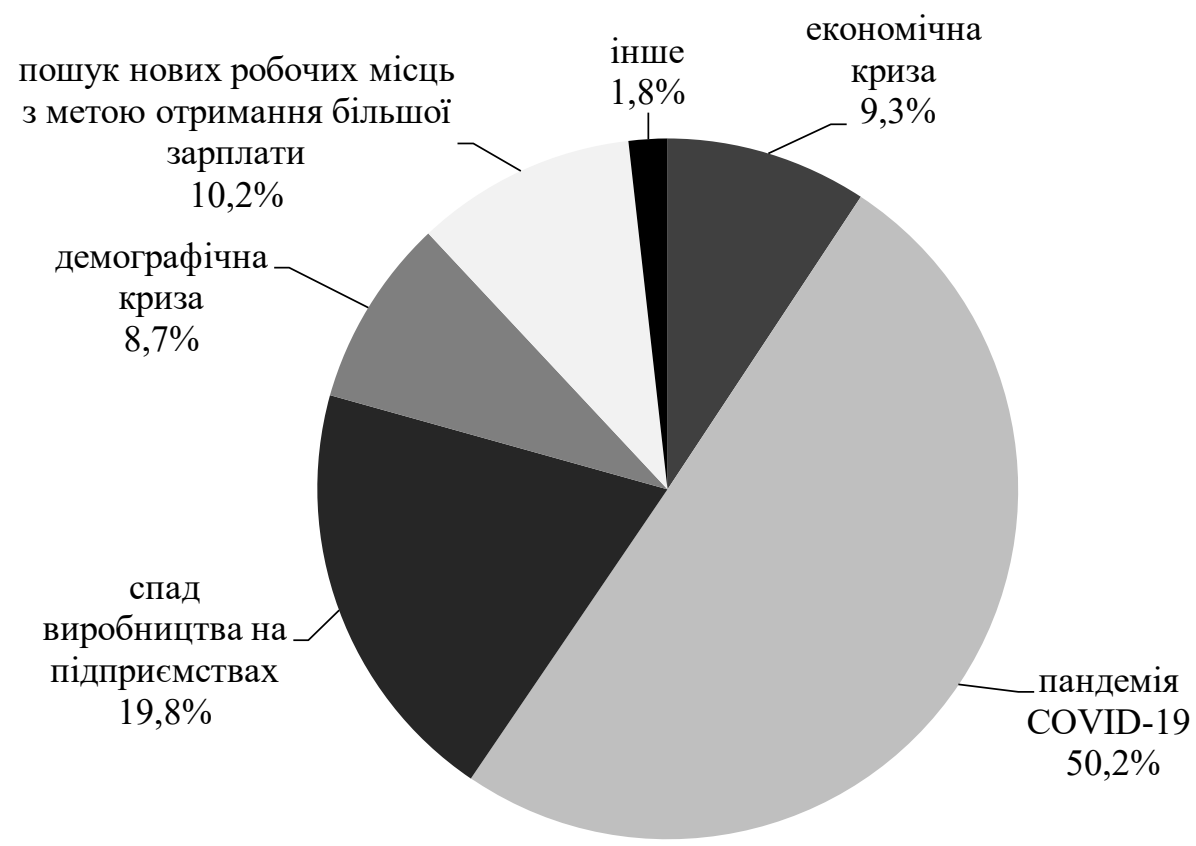

Рис. 2. Причини безробіття в умовах сьогодення на думку респондентів, \% респондентів

Джерело: розроблено авторами.

Важливо зауважити, що безробіття призводить до певних негативних соціальноекономічних наслідків та підвищує рівень соціальної напруги серед населення. На думку респондентів, найпоширенішим негативним наслідком безробіття в Україні є зростання злочинності (рис. 3). Більше того, безробіття впливає на зниження рівня життя населення та професійної кваліфікації, про що зазначили 18,8 та 18,5 \% респондентів відповідно. Не менше важливим наслідком безробіття є трудова міграція населення, а особливо найбільш кваліфікованих фахівців, найкращої робочої сили, яка досягла нині в Україні великих розмірів та становить значну загрозу для сучасного і майбутнього українського суспільства, оскільки це не тільки знижує людський потенціал населення регіонів, а й негативно впливає на конкурентоспроможність економіки країни загалом.

Крім того, респонденти зазначили, що позитивних наслідків безробіття не так і багато, серед них є такі: збільшення особистого вільного часу та створення конкуренції між працівниками. 


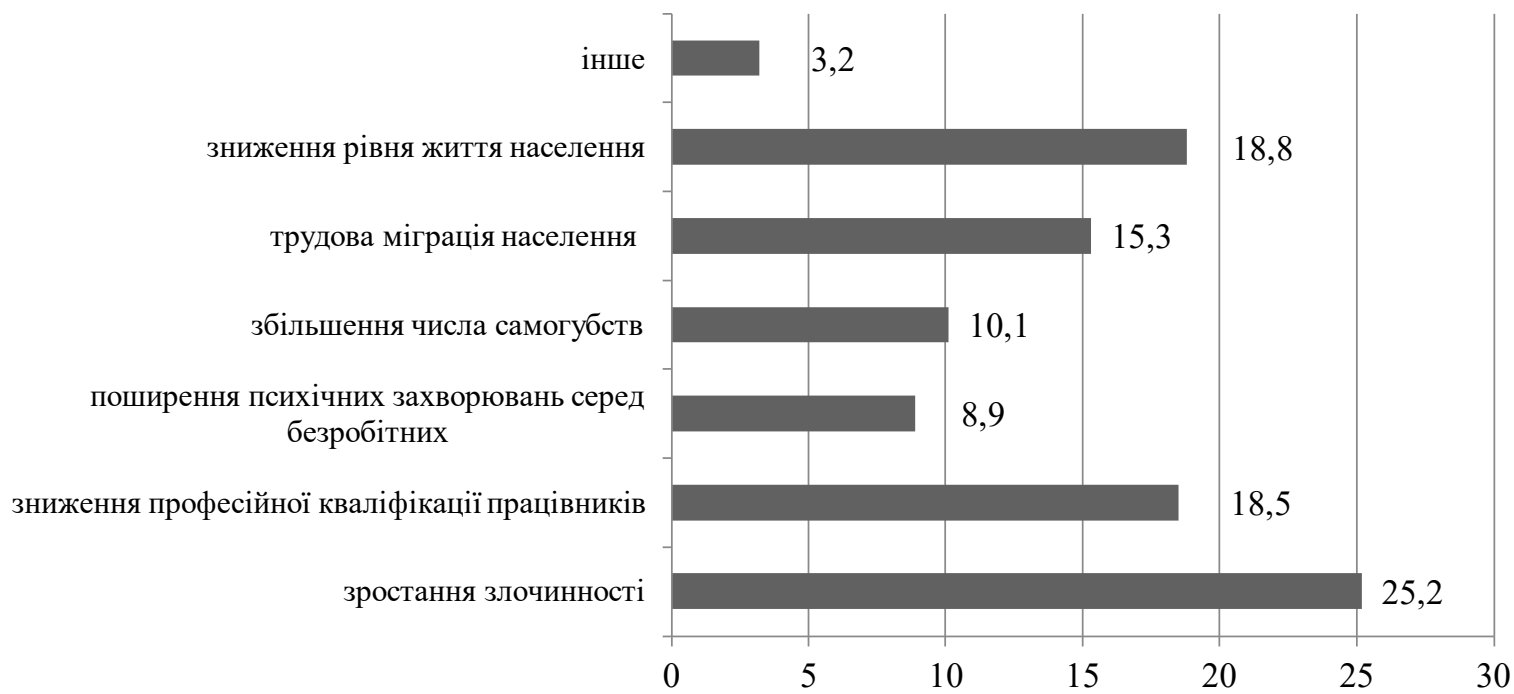

Рис. 3. Негативні соиіально-економічні наслідки безробіття на думку респондентів, \% опитаних

Джерело: розроблено авторами.

Респонденти вважають, що головними шляхами вирішення проблеми безробіття $\epsilon$ легалізація тіньової зайнятості (36,3\%, або 14 респондентів) та популяризація і державна підтримка самозайнятості (30,2\%, або 11 респондентів).

Не менш важливим напрямом подолання безробіття, на думку опитаних, $є$ розвиток дуальної освіти (15,3%), що сприятиме формуванню висококваліфікованої та конкурентоспроможної робочої сили в регіонах України.

Крім того, 7,7 \% опитаних переконані, що важливим напрямом подолання безробіття в Україні має бути інтеграція осіб з особливими потребами до ринку праці, оскільки ця категорія населення має значний потенціал. Проте через брак можливостей не має змоги використати цей потенціал у трудовій сфері.

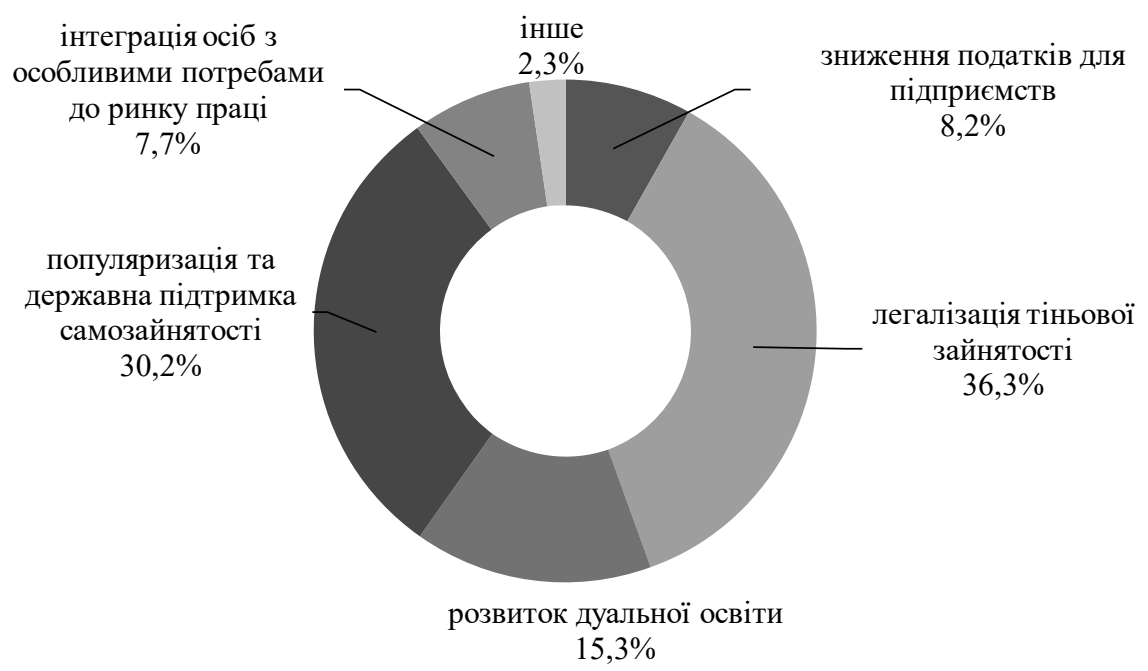

Рис 4. Напрями подолання безробіття на думку респондентів, \% опитаних Джерело: розроблено авторами.

Одним із дієвих прикладів інтеграції осіб з особливими потребами до ринку праці $є$ розвиток соціального підприємництва, яке не тільки має на меті отримання максимального прибутку, а й вирішення соціально значущих проблем громади, у тому числі й соціальне виключення осіб з особливими потребами. 
ТЕОРЕТИЧНІ ПРОБЛЕМИ РОЗВИТКУ НАЦІОНАЛЬНОЇ ЕКОНОМІКИ

Висновки і пропозиції. Отже, за результатами проведеного дослідження, можна зробити такі висновки. По-перше, безробіття - це явище не тільки економічне, а й соціальне. Воно безпосередньо пов'язане з діючою політикою держави, а в умовах глобалізації - з політикою міжнародних організацій. По-друге, значний негативний вплив на поширення безробіття в регіонах України мала пандемія COVID-19. По-третє, безробіття має суттєві соціально-економічні наслідки, серед яких варто виділити: зростання злочинності; зниження рівня життя населення регіонів; зниження професійної кваліфікації працівників; трудова міграція населення; збільшення числа самогубств та поширення психічних захворювань серед безробітних. По-четверте, ключовими напрямами подолання безробіття в регіонах України має бути: легалізація тіньової зайнятості; популяризація та державна підтримка самозайнятості; розвиток дуальної освіти; зниження податків для підприємств та інтеграція осіб з особливими потребами до ринку праці.

\section{Список використаних джерел}

1. Безробіття в Україні: причини, види, наслідки. Наукові доробки молоді виріменню проблем Європейської інтеграції : збірник наукових статей : у 2 т. Харків : Континент, 2008. Т. 2. С. 34-36.

2. Воробйов Є. М. Економічна теорія. Харків : ХНУ імені В. Н. Каразіна. 2019. 464 с.

3. Державна служба зайнятості України. Статистична інформація. URL: http://www.dcz.gov.ua/ control/uk/index.

4. Державна служба статистики Закарпатської області. Статистична інформація. URL: http://www.uz.ukrstat.gov.ua/index.html.

5. Дерій Ж. В., Скиба С. А. Формування ринку праці на основі розвитку людського потенціалу. Проблеми і перспективи економіки та управління. 2015. № 2. С. 9-17.

6. Економіка XXI: Міжнародний збірник наукових праць. Донецьк : Дон НТУ, 2009. Вип. 3. C. $44-47$.

7. Крамаренко К. М., Губарєв С. С. Безробіття населення як макроекономічна проблема. Молодий вчений. 2014. № 6(1). C. 147-150. URL: http://nbuv.gov.ua/UJRN/molv_2014_6\%281\%29_40.

8. Нечипоренко М. Безробіття в Україні наростає - як упоратися з тим державі / Українське національне інформаційне агентство «Укрінформ». 2020. URL: https://www.ukrinform.ua/rubricsociety/3008987-bezrobitta-v-ukraini-narostae-ak-uporatisa-z-tim-derzavi.html.

9. Нікіфоров П. О., Вольська А. О. Фінансово-економічні аспекти розвитку праці та боротьби з безробіттям. Фінанси Украӥни. 2008. № 10. С. 22-30. URL: http://nbuv.gov.ua/UJRN/Fu 2008_10_3.

10. Про зайнятість населення: Закон України від 05.07.2012 № 5067-VI. URL: https://zakon.rada.gov.ua/laws/show/5067-17\#Text.

11. Ревко А. М. Освітня домінанта у парадигмальному вимірі соціогуманітарного простору регіону : монографія. Чернігів : Видавець Брагинець О. В., 2019. 354 с.

12. Севрук О., Севрук Т. Проблема безробіття: міжнародний та вітчизняний досвід. Науковий часопис Національної академії прокуратури України. 2019. № 1(21). C. 76-84. URL: http://www.chasopysnapu.gp.gov.ua/ua/pdf/1-2019/sevruk.pdf.

13. Слюсар C. Т. Аналіз рівня безробіття в Україні: проблеми і шляхи його подолання. URL: https://journals.indexcopernicus.com/api/file/viewByFileId/664179.pdf.

14. Сучасний ринок праці. URL: https://ipf.npu.edu.ua/yak-shukaty-robotu/suchasnyi-rynokpratsi-ta-poshuk-roboty.

15. Тиждень UA. URL: http://tyzhden.ua/News/50545.

16. Юрій С., Буян I. Економічна теорія: політична економія. Київ : Кондор, 2009. 600 с.

\section{References}

1. Bezrobittia v Ukraini: prychyny, vydy, naslidky. Naukovi dorobky molodi vyrishenniu problem Yevropeiskoi intehratsii [Unemployment in Ukraine: Causes, Types, Consequences]. (2008). (vol. 2, pp. 34-36). Kontynent.

2. Vorobyov, E.M. (2019). Ekonomichna teoriia [Economic theory]. KhNU V.N. Karazin.

3. Derzhavna sluzhba zainiatosti Ukrainy [State Employment Service of Ukraine]. (n.d.). Statystychna informatsiia [Statistical information]. http://www.dcz.gov.ua/control/uk/index. 
4. Derzhavna sluzhba statystyky Zakarpatskoi oblasti [State Statistics Service of Zakarpattian region]. (n.d.). Statystychna informatsiia [Statistical information]. http://www.uz.ukrstat.gov.ua/index.html.

5. Derii, Zh.V., Skyba, S.A. (2015). Formuvannia rynku pratsi na osnovi rozvytku liudskoho potentsialu [Formation of the labor market based on the development of human potential]. Problemy $i$ perspektyvy ekonomiky ta upravlinnia - Problems and prospects of economics and management, (2), 9-17.

6. Ekonomika XXI: Mizhnarodnyi zbirnyk naukovykh prats [Economics XXI: International collection of scientific papers]. (2009), 3, 44-47. Don NTU.

7. Kramarenko, K.M., Gubarev, S.S. (2014). Bezrobittia naselennia yak makroekonomichna problema [Unemployment as a macroeconomic problem]. Molodyi vchenyi - Young Scientist, 6(1), 147-150. http://nbuv.gov.ua/UJRN/molv_2014_6\%281\%29_40.

8. Nechiporenko, M. (2020). Bezrobittia v Ukraini narostaie - yak uporatysia z tym derzhavi [Unemployment in Ukraine is rising - how to deal with it the state]. https://www.ukrinform.ua/rubricsociety/3008987-bezrobitta-v-ukraini-narostae-ak-uporatisa-z-tim-derzavi.html.

9. Nikiforov, P.O., Volskaya, A.O. (2008). Finansovo-ekonomichni aspekty rozvytku pratsi ta borotby $\mathrm{z}$ bezrobittiam [Financial and economic aspects of labor development and the fight against unemployment]. Finansy Ukrainy - Finance of Ukraine, (10), 22-30. http://nbuv.gov.ua/UJRN/ $\mathrm{Fu} \_2008 \_10 \_3$.

10. Pro zainiatist naselennia [On Employment of Population], Law of Ukraine № 5067-VI (on July 5, 2012). https://zakon.rada.gov.ua/laws/show/5067-17?lang=en\#Text.

11. Revko, A.M. (2019). Osvitnia dominanta u paradyhmalnomu vymiri sotsiohumanitarnoho prostoru rehionu [Educational dominant in the paradigmatic dimension of the socio-humanitarian space of the region]. Vydavets Brahynets O.V.

12. Sevruk, O., Sevruk, T. (2019). Problema bezrobittia: mizhnarodnyi ta vitchyznianyi dosvid [The problem of unemployment: international and domestic experience]. Naukovyi chasopys Natsionalnoi akademii prokuratury Ukrainy - Scientific journal of the National Academy of the Prosecutor's Office of Ukraine, (1(21), 76-84. http://www.chasopysnapu.gp.gov.ua/ua/pdf/1-2019/sevruk.pdf.

13. Sliusar, S.T. (2018). Analiz rivnia bezrobittia v Ukraini: problemy i shliakhy yoho podolannia. [Analysis of the unemployment rate in Ukraine: problems and ways to overcome it]. https://journals.indexcopernicus.com/api/file/viewByFileId/664179.pdf.

14. Suchasnyi rynok pratsi [Modern labor market]. https://ipf.npu.edu.ua/yak-shukatyrobotu/suchasnyi-rynok-pratsi-ta-poshuk-roboty.

15. Tyzhden UA [Week UA]. http://tyzhden.ua/News/50545.

16. Yuri, S., Buyan, I. (2009). Ekonomichna teoriia: politychna ekonomiia [Economic theory: political economy]. Kondor.

Ревко Альона Миколаївна - доктор економічних наук, доцент, професор кафедри соціальної роботи, Національний університет «Чернігівська політехніка» (вул. Шевченка, 95, м. Чернігів, 14035, Україна).

Revko Alona - Doctor of Economics, Associate Professor, Professor of the Department of Social Work, Chernihiv

Polytechnic National University (95 Shevchenka Str., Chernihiv, 14035, Ukraine).

E-mail: alohaha19@gmail.com

ORCID: http://orcid.org/0000-0001-7888-3657

ResearcherID: AAX-2013-2020

Приходыко Наталія Вікторівна - магістр, Національний університет «Чернігівська політехніка» (вул. Шевченка, 95, м. Чернігів, 14035, Україна).

Pryhodko Natalia - Master Student, Chernihiv Polytechnic National University (95 Shevchenka Str., Chernihiv, 14035, Ukraine).

Ревко А., Приходько Н. Соціально-економічні наслідки безробіття населення регіонів України. Проблеми $i$ перспективи економіки та управління. 2021. № 2(26). С. 18-24. 